\title{
Two Distinct Heterotypic Channels Mediate Gap Junction Coupling between Astrocyte and Oligodendrocyte Connexins
}

\author{
Jennifer L. Orthmann-Murphy, ${ }^{1}$ Mona Freidin, ${ }^{2}$ Esther Fischer, ${ }^{2}$ Steven S. Scherer, ${ }^{1}$ and Charles K. Abrams ${ }^{2}$ \\ ${ }^{1}$ Department of Neurology, University of Pennsylvania School of Medicine, Philadelphia, Pennsylvania 19104-6077, and ${ }^{2}$ Department of Neurology, State \\ University of New York Downstate Medical Center, Brooklyn, New York 11203
}

Genetic diseases demonstrate that the normal function of CNS myelin depends on connexin32 (Cx32) and Cx47, gap junction (GJ) proteins expressed by oligodendrocytes. GJs couple oligodendrocytes and astrocytes (0/A channels) as well as astrocytes themselves (A/A channels). Because astrocytes express different connexins ( $\mathrm{Cx} 30$ and $\mathrm{Cx} 43$ ), $\mathrm{O} / \mathrm{A}$ channels must be heterotypic, whereas $\mathrm{A} / \mathrm{A}$ channels may be homotypic or heterotypic. Using electrophysiological and immunocytochemical approaches, we found that $\mathrm{Cx} 47 / \mathrm{Cx} 43$ and $\mathrm{Cx} 32 / \mathrm{Cx} 30$ efficiently formed functional channels, but other potential heterotypic $\mathrm{O} / \mathrm{A}$ and $\mathrm{A} / \mathrm{A}$ pairs did not. These results suggest that $\mathrm{Cx} 30 / \mathrm{Cx} 30$ and $\mathrm{Cx} 43 / \mathrm{Cx} 43$ channels mediate $\mathrm{A} / \mathrm{A}$ coupling, and $\mathrm{Cx} 47 / \mathrm{Cx} 43$ and $\mathrm{Cx} 32 / \mathrm{Cx} 30$ channels mediate $\mathrm{O} / \mathrm{A}$ coupling. Furthermore, $\mathrm{Cx} 47 / \mathrm{Cx} 43$ and $\mathrm{Cx} 32 / \mathrm{Cx} 30$ channels have distinct macroscopic and single-channel properties and different dye permeabilities. Finally, $\mathrm{Cx} 47$ mutants that cause Pelizaeus-Merzbacher-like disease do not efficiently form functional channels with $\mathrm{Cx} 43$, indicating that disrupted $\mathrm{Cx} 47 / \mathrm{Cx} 43$ channels cause this disease.

Key words: gap junction; glia; myelin; connexin; astrocytes; oligodendrocytes

\section{Introduction}

Gap junctions (GJs) are intercellular channels that form between apposed cell membranes to permit the diffusion of ions and small molecules < $1000 \mathrm{Da}$ (Bruzzone et al., 1996). In vertebrates, GJs are comprised of connexins (Cxs): a family of highly conserved integral membrane proteins that are usually named according to their predicted molecular mass (Willecke et al., 2002). Six connexins oligomerize into a hemichannel (or connexon), and two apposing hemichannels form the GJ; aggregates of tens to thousands of intercellular channels form a GJ plaque. The potential diversity of GJ composition is immense, as over 20 mammalian connexins have been described. Hemichannels may be homomeric, containing one type of connexin, or heteromeric, containing more than one type. GJs are termed homotypic if the apposed hemichannels contain the same connexin, and heterotypic if they contain different connexins.

Anatomical and functional studies of the mammalian CNS have demonstrated that astrocytes and oligodendrocytes are coupled by GJs, forming a "glial syncytium" (Mugnaini, 1986; Rash et al., 2001). There are abundant GJs between astrocytes (A/A), fewer between oligodendrocytes and astrocytes (O/A), and none between oligodendrocytes. Astrocytes express Cx30 and Cx43

Received July 26, 2007; revised 0ct. 11, 2007; accepted 0ct. 22, 2007.

This work was supported by the National Multiple Sclerosis Society and National Institutes of Health Grants NS054363 (J.L.O.-M.), NS55284, and NS043560 (S.S.S.), and NS50345 and NS050705 (C.K.A.). We thank Jeff Rossi, Dr. Josep Dalmau, and Alan D. Enriquez for technical help, Dr. Dan Heitjan and Meg Ballard for statistical advice, Dr. Sabrina Yum for the HeLa cells that stably express $\mathrm{C} \times 30$, and Dr. Edgardo Arroyo for advice on graphic art.

Correspondence should be addressed to Jennifer Orthmann-Murphy, University of Pennsylvania Medical Center Room 464 Stemmler Hall, 3450 Hamilton Walk, Philadelphia, PA 19104-6077. E-mail: lorthman@ mail.med.upenn.edu.

DOI:10.1523/JNEUROSCI.3395-07.2007

Copyright $\odot 2007$ Society for Neuroscience $\quad$ 0270-6474/07/2713949-09\$15.00/0
(Dermietzel et al., 1989; Ochalski et al., 1997; Nagy et al., 1999), but probably not Cx26 as reported previously (Nagy et al., 2001), because lac $Z$ was not detected in astrocytes in a Cx26 reporter mouse (Filippov et al., 2003). A/A coupling appears to be mediated by homotypic channels ( $\mathrm{Cx} 43 / \mathrm{Cx} 43$ and $\mathrm{Cx} 30 / \mathrm{Cx} 30)$ (Swenson et al., 1989; Werner et al., 1989; Dahl et al., 1996), but it is unknown whether these connexins can also form heteromeric hemichannels or heterotypic channels. Oligodendrocytes express Cx32 and Cx47 (Scherer et al., 1995; Menichella et al., 2003; Odermatt et al., 2003), as well as Cx29, which does not appear to form GJs (Altevogt et al., 2002; Kleopa et al., 2004) (cf. Nagy et al., 2003b), so that O/A coupling must be mediated by heterotypic channels. The possible candidates for O/A junctions are $\mathrm{Cx} 47 / \mathrm{Cx} 43, \mathrm{Cx} 32 / \mathrm{Cx} 30, \mathrm{Cx} 43 / \mathrm{Cx} 32$, or $\mathrm{Cx} 47 / \mathrm{Cx} 30$ channels (Nagy et al., 2003a; Altevogt and Paul, 2004), but their compatibility has not been directly evaluated. Whether the oligodendrocyte connexins also form heteromeric hemichannels is unknown.

Genetic evidence indicates that normal function of CNS myelin in humans depends on oligodendrocyte connexins. Mutations in the genes encoding Cx47 (GJA12) and Cx32 (GJB1) cause Pelizaeus-Merzbacher-like disease (PMLD) and the X-linked form of Charcot-Marie-Tooth disease type 1 (CMTX), respectively. PMLD is a devastating dysmyelinating disease that is clinically similar to Pelizaeus-Merzbacher disease, but is caused by recessive GJA12 mutations (Uhlenberg et al., 2004). These recessive mutations result in loss-of-function of Cx47 (OrthmannMurphy et al., 2007). CMTX is an inherited demyelinating neuropathy (Scherer and Kleopa, 2005) rarely associated with overt CNS dysfunction (Taylor et al., 2003). These phenotypes suggest that $\mathrm{Cx} 47$ is more important for $\mathrm{O} / \mathrm{A}$ coupling than is $\mathrm{Cx} 32$. We show here that O/A channels are potentially comprised of $\mathrm{Cx} 32 /$ $\mathrm{Cx} 30$ and $\mathrm{Cx} 47 / \mathrm{Cx} 43$, that these channels have unique proper- 
ties, and that $\mathrm{Cx} 47$ mutants do not form functional channels with $\mathrm{Cx} 43$, thereby implicating the loss of $\mathrm{Cx} 47 / \mathrm{Cx} 43$ channels as the mechanism causing PMLD.

\section{Materials and Methods}

Human Cx30, Cx32, Cx43, and Cx47 expression constructs. The human $\mathrm{Cx} 30, \mathrm{Cx} 32$, and $\mathrm{Cx} 47$ clones were generated as described previously (Abrams et al., 2006; Orthmann-Murphy et al., 2007). The human Cx43 open reading frame was generated similarly to the $\mathrm{Cx} 47$ clone, using primers based on the GenBank accession number NM_000165 DNA sequence, by reverse transcription-PCR (SuperScript II; Invitrogen, Carlsbad, CA). Each connexin was subcloned into the bicistronic vectors pIRES2-EGFP (Clontech, Mountain View, CA) and pIRES2-DsRed; the latter was generated by replacing the enhanced green fluorescent protein (EGFP) sequence of the former with PCR amplified coding sequence for monomeric DsRed (from pDsRed-N1; Clontech), using primers that added BstXI and NotI restriction sites to the $5^{\prime}$ and $3^{\prime}$ ends, respectively. The resulting plasmids were used to transform DH5- $\alpha$ bacteria; a largescale plasmid preparation was made from a single colony (Sigma, St. Louis, MO) and analyzed at the Sequencing Core of the University of Pennsylvania.

Transfections. Neuro2A cells (from American Type Culture Collection, Manassas, VA) and communication-incompetent HeLa cells (gift from Dr. Klaus Willecke, University of Bonn, Bonn, Germany) were maintained as described previously (Orthmann-Murphy et al., 2007). Transient transfection of Neuro2A cells for electrophysiology and generation of bulk-selected HeLa cell lines have been described previously (Orthmann-Murphy et al., 2007). Bulk-selected cells were diluted and single colonies were selected, expanded and maintained in $0.5 \mu \mathrm{g} / \mathrm{ml}$ puromycin-supplemented media (Sigma).

To prelabel cells, bulk-selected HeLa cells stably expressing Cx30, $\mathrm{Cx} 32, \mathrm{Cx} 43$, or $\mathrm{Cx} 47$ (in at least $90 \%$ of cells) were transiently transfected to express DsRed by incubating pDsRed-N1 DNA, PLUS reagent, and Lipofectamine LTX (Invitrogen) for $30 \mathrm{~min}$ before addition to confluent cells. Twenty-four hours later, cells were trypsinized and mixed in pairs in a ratio of 1 (DsRed + ) to 20 (DsRed - ) and plated on $10 \mathrm{~mm}$ glass coverslips. Twenty-four hours later, pairs were fixed with $4 \%$ paraformaldehyde for $10 \mathrm{~min}$ at $4^{\circ} \mathrm{C}$ and immunostained with various combinations of primary antibodies: rabbit anti-Cx30 (Zymed, Carlsbad, CA; diluted 1:1000), rabbit anti-Cx32 (Chemicon, Temecula, CA; 1:500), rabbit anti-Cx47 (Orthmann-Murphy et al., 2007) (1:1500), biotinylated rabbit anti-Cx47 (generated as described previously; 1:10000) (Furneaux et al., 1990), mouse anti-Cx32 (7C6C7; 1:1) or mouse anti-Cx43 (Chemicon; 1:750), as described previously (Orthmann-Murphy et al., 2007). Secondary antibodies were conjugated with FITC or Cy5 (Jackson ImmunoResearch Laboratories, West Grove, PA). The coverslips were washed, counterstained with DAPI, mounted with Vectashield (Vector Laboratories, Burlingame, CA), and imaged using FITC, tetramethylrhodamine isothiocyanate, and Cy 5 filters and a $63 \times$ objective on a Leica (Wetzlar, Germany) fluorescence microscope with a Hamamatsu (Shizuoka, Japan) digital camera C4742-95 connected to a G5 Macintosh (Apple, Cupertino, CA) computer running Openlab 3.1.7 (Improvision, Waltham, MA) or with a Leica laser scanning confocal microscope.

Analysis of heterotypic mixes: immunocytochemical experiments. Epifluorescence images were imported into Adobe (San Jose, CA) Photoshop and the level of each channel was adjusted so that fluorescent signal ranged from 0 to 255. DsRed and Cy5 channels were pseudocolored blue and red, respectively. We found that most DsRed+ cells also exhibited immunostaining of the appropriate connexin. For each DsRed + cell, we determined whether connexin puncta (defined as focal aggregations of the fluorescence) appeared to be localized intracellularly (contained within the DsRed signal) or at the cell membrane (at the periphery of the DsRed signal). We excluded DsRed + cells lacking connexin immunostaining, but not DsRed + cells exhibiting only cytoplasmic connexin staining. We then determined whether the cell membrane puncta overlapped with those of the connexin expressed by the surrounding DsRedcells. For certain mixtures (e.g., Cx43 and $\mathrm{Cx} 47$ ), some cytoplasmic puncta overlapped with those of the connexin expressed by the sur- rounding DsRed- cells, but these were not included in the analysis. These could represent internalized gap junctions (Yeager et al., 1998). At least 5 DsRed + cells from two coverslips were analyzed for each heterotypic mixture; this was repeated in three independent experiments. For each DsRed + cell, we determined the mean and 95\% confidence interval of the number of overlapping cell surface puncta. The number of DsRed + cells with or without one or more overlapping puncta were compared using Fisher's exact test with Bonferroni's correction for multiple comparisons. All statistical tests were performed in GraphPad (San Diego, CA) Prism.

Heterotypic pairings and recording from transfected mammalian cell lines. Confluent Neuro2A cells were transiently transfected with $\mathrm{Cx} 30$, Cx32, Cx43, or Cx47 subcloned into pIRES2-EGFP or pIRES2-DsRed. One day later, transfected cells were washed and cells expressing a pIRES2-EGFP construct were mixed with cells expressing a pIRES2DsRed construct, then plated on poly-D-lysine-coated $10 \mathrm{~mm}$ coverslips. Dual whole-cell voltage clamping of pairs of cells and analyses were performed as described previously (Abrams et al., 2003). Recording solutions used were as follows (in $\mathrm{mm}$ ): pipette solution, $145 \mathrm{CsCl}, 5 \mathrm{EGTA}$, $0.5 \mathrm{CaCl}_{2}$, and 10.0 HEPES, pH 7.2; bath solution, $150 \mathrm{NaCl}, 4 \mathrm{KCl}, 1$ $\mathrm{MgCl}_{2}, 2 \mathrm{CaCl}_{2}, 5$ dextrose, 2 pyruvate, and 10 HEPES, pH 7.4. Junctional conductance $\left(G_{\mathrm{j}}\right)$ was determined from isolated pairs by measuring instantaneous junctional current $\left(I_{\mathrm{j}}\right)$ responses to junctional voltage $\left(V_{\mathrm{j}}\right)$ pulses from 0 to \pm 40 or $\pm 100 \mathrm{mV}$ and applying Ohm's law. Cytoplasmic bridges were excluded by demonstrating the sensitivity of $G_{j}$ to application of bath solution containing octanol or saturated with $\mathrm{CO}_{2}$. Values are presented as mean $G_{j} \pm$ SEM, and were compared using a Kruskal-Wallis test with Dunn's post-test for multiple comparisons.

Dye-transfer studies. Dye-transfer studies were performed as described previously (Abrams et al., 2006). Briefly, intercellular dye transfer was measured by monitoring fluorescence intensity in both cells of a pair after loading one cell with dye via patch pipette in whole-cell configuration. After $>5 \mathrm{~min}$, whole-cell recording configuration was established with the second cell to verify coupling, and heptanol was applied to rule out coupling attributable to a cytoplasmic bridge. Dyes used include Lucifer yellow [LY; molecular weight (MW), 443; valence, -2] and Alexa Fluor350 (AF350; MW, 350; valence, -1), which were purchased from Invitrogen. Each dye was examined in at least five cell pairs. Fluorescence signals were recorded using a SPOT RT (Diagnostic Instruments, Sterling Heights, MI) with slider digital camera mounted on an Olympus (Tokyo, Japan) IX70 microscope and Metafluor software (Molecular Devices, Sunnyvale, CA).

\section{Results}

\section{$\mathrm{Cx} 32 / \mathrm{Cx} 30$ and $\mathrm{Cx} 47 / \mathrm{Cx} 43$ gap junctions selectively assemble} in a mammalian cell line

To determine whether connexins expressed by astrocytes $(\mathrm{Cx} 43$ and $\mathrm{Cx} 30)$ and oligodendrocytes (Cx32 and $\mathrm{Cx} 47)$ form heterotypic GJ plaques, we generated HeLa cell lines in which at least $90 \%$ of cells stably expressed human Cx30, Cx32, Cx43, or Cx47. We transiently transfected each cell line to express DsRed (DsRed + cells) and individually mixed these cells with DsRedcells expressing one of the other connexins, at a ratio of 1 to 20 . These mixtures are designated as " $\mathrm{CxA}^{\star} / \mathrm{CxB}$," where the asterisk denotes the connexin expressed by the DsRed + cell. We immunostained cells after $24 \mathrm{~h}$, and found that the majority of DsRed+ cells expressed the relevant connexin; for each of these cells, we determined whether connexin puncta were localized to the cell membrane (at the periphery of DsRed signal). As summarized in supplemental Table 1 (available at www.jneurosci.org as supplemental material), nearly all DsRed + cells contained at least one punctum at the cell membrane, independent of the connexins paired in the mixture.

We then determined whether the connexin puncta of the DsRed + cell overlapped with connexin puncta of the surrounding DsRed- cells. Cell mixtures containing Cx30 and Cx32 or Cx43 and Cx47 formed overlapping puncta at cell borders, in 
$\mathrm{O} / \mathrm{A}$
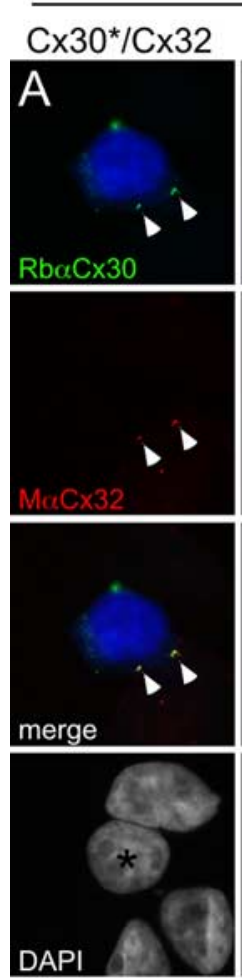

$\mathrm{F}$$$
\mathrm{F}
$$
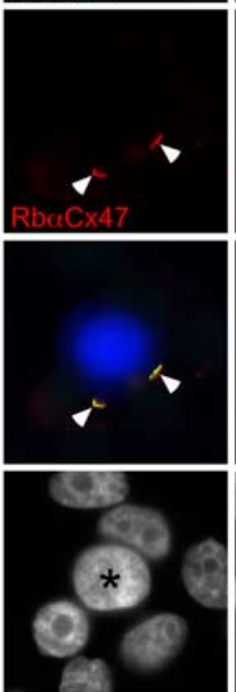
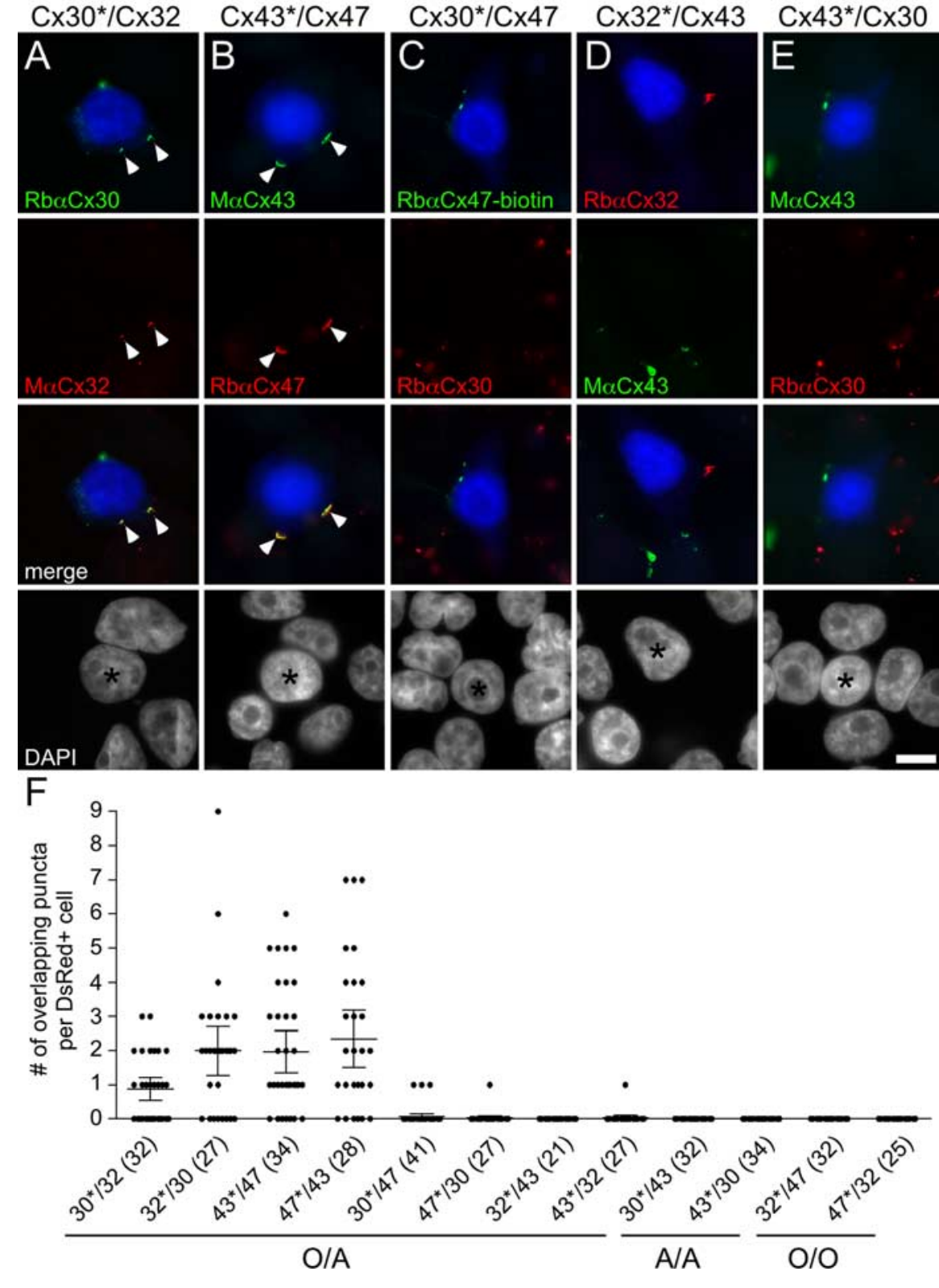

Figure 1. $\mathrm{C} \times 32 / \mathrm{C} \times 30$ and $\mathrm{Cx} 47 / \mathrm{Cx} 43$ form overlapping puncta. $\boldsymbol{A}-\boldsymbol{E}$, HeLa cells stably expressing $\mathrm{Cx} 30, \mathrm{C} \times 32, \mathrm{Cx} 43$, or $\mathrm{Cx} 47$ were transiently transfected to express DsRed (DsRed + ) and mixed with DsRed - cells in a ratio of 1 to 20 . After $24 \mathrm{~h}$, cells were immunostained as indicated, and counterstained for DAPI. One of the two possible pairings for each combination is illustrated. The DsRed + cell is pseudocolored blue in the first and third rows, and indicated by an asterisk in the fourth row. Note that examples of $\mathrm{C} \times 32 / \mathrm{C} \times 30(\boldsymbol{A})$ and $\mathrm{Cx} 47 / \mathrm{C} \times 43(\boldsymbol{B})$ mixtures have overlapping puncta (arrowheads), whereas $\mathrm{C} \times 47 / \mathrm{C} \times 30(\boldsymbol{C}), \mathrm{C} \times 43 / \mathrm{C} \times 32(\boldsymbol{D})$, and

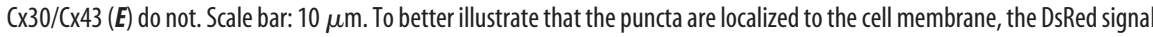
is enhanced in these images in supplemental Figure 1 (available at www.jneurosci.org as supplemental material). $\boldsymbol{F}$, Quantitative summary of three independent experiments. For each mixture, an asterisk denotes the DsRed + cell. Each dot shows the number of overlapping puncta determined for 1 DsRed + cell. In each column, the horizontal bar denotes the mean, the vertical bar represents the $95 \%$ confidence interval, and the total number of DsRed + cells is shown in parentheses. Only mixtures of $\mathrm{Cx} 32 / \mathrm{C} \times 30\left(30^{*} / 32\right.$ and $\left.32^{*} / 30\right)$ and $\mathrm{C} \times 47 / \mathrm{C} \times 43\left(43^{*} / 47\right.$ and $\left.47^{*} / 43\right)$ have overlapping puncta, in contrast to the other mixtures. The discrepancy between the number of overlapping puncta for $\mathrm{C} \times 30^{*} / \mathrm{C} \times 32$ relative to $\mathrm{C} \times 32^{*} / \mathrm{C} \times 30$ is likely caused by lower expression of $\mathrm{C} \times 32$. $\boldsymbol{A}-\boldsymbol{F}$, The mixtures are designated as potential $0 / \mathrm{A}, \mathrm{A} / \mathrm{A}$, or $0 / 0$ pairs.

contrast to the other cell mixtures (Cx30 and Cx47, Cx32 and $\mathrm{Cx} 43, \mathrm{Cx} 30$ and $\mathrm{Cx} 43$, and $\mathrm{Cx} 32$ and $\mathrm{Cx} 47)$, which rarely resulted in overlapping puncta (Fig. 1, supplemental Fig. 1), although the DsRed + cell had cell surface puncta (supplemental Table 1, available at www.jneurosci.org as supplemental material). We repeated this experiment three times for each mixture of connexins,
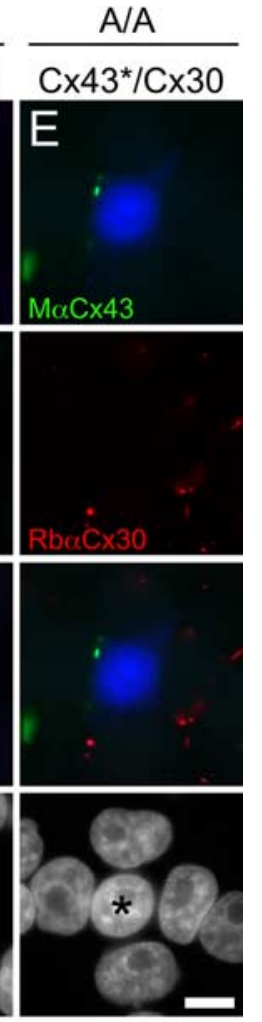

with similar results. To confirm that puncta overlapped and were not just superimposed, we examined $z$ stacks obtained by confocal microscopy (data not shown). To rule out the possibility that antibodies cross-react, we immunostained each cell line expressing a particular connexin with each antibody used in this analysis. In every case, only the appropriate antibodies labeled the cell line (data not shown).

To quantify these results, we counted the number of puncta at the cell membrane of each DsRed + cell, and determined whether these puncta overlapped with the connexin expressed by the surrounding DsRed- cells. These results are summarized in Figure $1 F$ and Table 1. In mixtures containing $\mathrm{Cx} 32 / \mathrm{Cx} 30$ or Cx47/Cx43, most DsRed + cells formed one or more overlapping puncta; this was seen for all possible pairings, independent of which connexin was expressed by the DsRed + cell $\left(\mathrm{C} \times 30^{*} /\right.$ $\mathrm{Cx} 32, \mathrm{Cx} 32^{*} / \mathrm{Cx} 30, \mathrm{Cx} 43^{*} / \mathrm{Cx} 47$, and $\left.\mathrm{Cx} 47^{\star} / \mathrm{Cx} 43\right)$. In contrast, only one $\mathrm{Cx} 43^{*} / \mathrm{Cx} 32$ pair and three $\mathrm{Cx} 30^{*} / \mathrm{Cx} 47$ pairs exhibited a single, overlapping punctum. Mixtures containing Cx32/ $\mathrm{Cx} 30$ or $\mathrm{Cx} 47 / \mathrm{Cx} 43$ produced a significantly larger proportion of DsRed + cells with at least one overlapping punctum, than did mixtures containing $\mathrm{Cx} 47 /$ $\mathrm{Cx} 30, \mathrm{Cx} 43 / \mathrm{Cx} 32, \mathrm{Cx} 30 / \mathrm{Cx} 43$, or $\mathrm{Cx} 32 /$ Cx47 ( $p<0.0001$, Fisher's test).

\section{Cx32/Cx30 and $\mathrm{Cx} 47 / \mathrm{Cx} 43$ efficiently form functional channels}

The immunocytochemical experiments suggest that $\mathrm{Cx} 32 / \mathrm{Cx} 30$ and $\mathrm{Cx} 47 / \mathrm{Cx} 43$ can form plaques, the morphological correlate of GJs. To address which channels are functional, we used dual wholecell patch clamping on pairs of Neuro2A cells, a sensitive technique for detecting functional channels. In these experiments, each cell was transiently transfected to express a single connexin as well as EGFP or monomeric DsRed, so that each member of a cell pair could be unambiguously identified. For negative control pairs, cells expressing a single connexin were paired with cells expressing EGFP or DsRed alone (Cx/CTR). As summarized in Figure 2 (supplemental Table 2, available at www.jneurosci.org as supplemental material), all homotypic pairs were well coupled as described previously (Werner et al., 1989; Barrio et al., 1991; Dahl et al., 1996; Teubner et al., 2001). Of the heterotypic pairings, only Cx $32 / C \times 30$ and $C x 47 /$ Cx43 pairs were similarly well coupled; their normalized $G_{j}$ was $\sim 100$ times greater than those of the other heterotypic pairs. To confirm that the bicistronic constructs used in the 
Table 1. Cx30, Cx32, Cx43, and Cx47 selectively form heterotypic pairs.

\begin{tabular}{ccccc}
\hline & \multicolumn{4}{c}{ Surround } \\
\cline { 2 - 5 } Center & $\mathrm{C} \times 30$ & $\mathrm{C} \times 32$ & $\mathrm{C} \times 43$ & $\mathrm{C} 477$ \\
\hline $\mathrm{C} \times 30$ & $\mathrm{NQ}$ & $56 \pm 8 \%$ & $0 \pm 0 \%$ & $8 \pm 5 \%$ \\
& & $(4 / 10,6 / 9,8 / 13)$ & $(0 / 11,0 / 10,0 / 12)$ & $(2 / 12,1 / 17,0 / 15)$ \\
$\mathrm{C} \times 32$ & $77 \pm 13 \%$ & $\mathrm{NQ}$ & $0 \pm 0 \%$ & $0 \pm 0 \%$ \\
& $(6 / 6,5 / 9,10 / 13)$ & & $(0 / 8,0 / 9,0 / 14)$ & $(0 / 9,0 / 11,0 / 13)$ \\
$\mathrm{C} \times 43$ & $0 \pm 0 \%$ & $3 \pm 3 \%$ & $\mathrm{NQ}$ & $79 \pm 2 \%$ \\
& $(0 / 12,0 / 11,0 / 13)$ & $(1 / 13,0 / 5,0 / 10)$ & & $(7 / 9,10 / 13,10 / 12)$ \\
Cx47 & $3 \pm 3 \%$ & $0 \pm 0 \%$ & $80 \pm 6 \%$ & $\mathrm{NQ}$ \\
& $(1 / 11,0 / 12,0 / 11)$ & $(0 / 7,0 / 7,0 / 11)$ & $(9 / 10,7 / 9,7 / 10)$ & \\
\hline
\end{tabular}

HeLa cells stably expressing $\mathrm{C} \times 30, \mathrm{C} 32, \mathrm{C} \times 43$, or $\mathrm{C} \times 47$ were transiently transfected to express DsRed, mixed in a ratio of 1 DsRed + cell (center) to 20 DsRed - cells (surround), and immunostained for each connexin in the pair after $1 \mathrm{~d}$. The number of connexin puncta on the cell membrane of the DsRed + cell that overlap with puncta of the connexin expressed by the surrounding cells was determined. The table shows the percentage (mean \pm SEM) of DsRed + cells with at least one overlapping punctum; the number of DsRed + cells with at least one overlapping punctum per the total number of DsRed + cells from each of three separate experiments are given in parentheses. NQ, Not quantified.

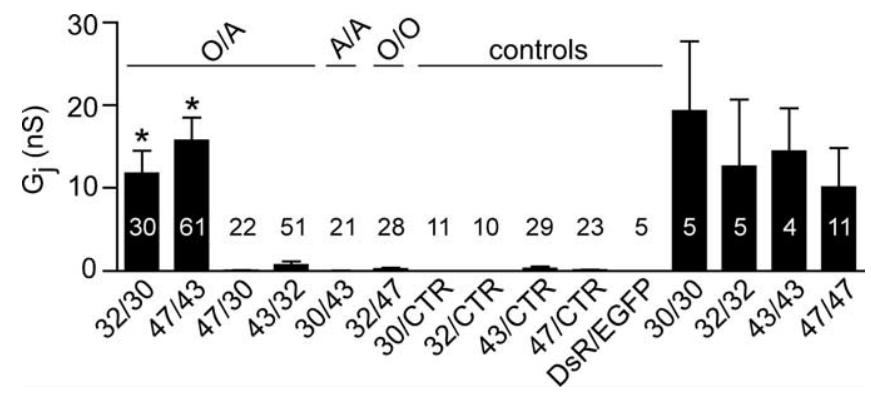

Figure 2. $\quad C \times 32 / C \times 30$ and $C \times 47 / C \times 43$ form functional channels. Neuro2A cells were transiently transfected with pIRES2-EGFP or pIRES2-DsRed vectors containing Cx30, Cx32, Cx43, Cx47, or no insert [vector alone control (CTR)]. After 24 h, EGFP- and DsRed-expressing cells were mixed in a 1 to 1 ratio; pairs were assessed by dual whole-cell patch clamping 6-48 $\mathrm{h}$ later. For each combination listed on the $x$-axis, the mean and SE of the $G_{j}$ and number of pairs tested is shown. Using a Kruskal-Wallis test followed by Dunn's multiple comparison test, only $\mathrm{C} \times 32 / \mathrm{C} \times 30$ and $\mathrm{C} \times 47 / \mathrm{C} \times 43$ channels have $G_{\mathrm{j}}$ that is significantly greater $\left({ }^{*} p<0.001\right)$ than those of the corresponding control pairs (32/CTR and 30/CTR or 43/CTR and 47/CTR).

above electrophysiology analysis were expressed, we immunostained transiently transfected Neuro2A cells, and found that they expressed the expected connexin and either EGFP or DsRed (supplemental Fig. 2, available at www.jneurosci.org as supplemental material).

The $G_{j}$ values for $\mathrm{Cx} 32 / \mathrm{Cx} 30$ and $\mathrm{Cx} 47 / \mathrm{Cx} 43$ pairs were significantly different from all other heterotypic pairings (supplemental Table 3, available at www.jneurosci.org as supplemental material). The $G_{\mathrm{j}}$ values of the other potential O/A $(\mathrm{Cx} 47 / \mathrm{Cx} 30, \mathrm{Cx} 43 / \mathrm{Cx} 32)$ and $\mathrm{A} / \mathrm{A}(\mathrm{Cx} 30 / \mathrm{Cx} 43)$ pairs were low and not significantly different from each other. This small amount of $G_{\mathrm{j}}$ is probably attributable to the formation of heterotypic channels with an endogenous connexin expressed by parental Neuro2A cells (Orthmann-Murphy et al., 2007), because some Cx43/CTR and Cx47/CTR pairs showed low levels of coupling. However, Cx30/CTR and Cx32/CTR pairs were never coupled (supplemental Table 2; for examples of single channels formed by $\mathrm{Cx} 43 / \mathrm{CTR}$ and $\mathrm{Cx} 47 / \mathrm{CTR}$ pairs, see supplemental Fig. 3, available at www.jneurosci.org as supplemental material). The $G_{\mathrm{j}}$ values of $\mathrm{Cx} 47 / \mathrm{Cx} 30, \mathrm{Cx} 43 / \mathrm{Cx} 32$, $\mathrm{Cx} 30 / \mathrm{Cx} 43$, and $\mathrm{Cx} 32 / \mathrm{Cx} 47$ pairs were not significantly different from those of the corresponding negative control pairs; thus, these four pairings do not appear to efficiently form functional channels.

\section{$\mathrm{Cx} 32 / \mathrm{Cx} 30$ and $\mathrm{Cx} 47 / \mathrm{Cx} 43$ channels have different functional properties}

To define the electrophysiological properties of $\mathrm{Cx} 32 / \mathrm{Cx} 30$ and $\mathrm{Cx} 47 / \mathrm{Cx} 43$ channels, we examined their macroscopic and single channel records. By convention, the pairing designation for recorded pairs is cell 2/cell 1; voltage ramps or steps were applied to cell 1 (making $V_{\mathrm{j}}$ equal to the voltage in cell 1 minus the voltage in cell 2), and current responses were measured in cell 2. An example of macroscopic current responses for Cx32/ Cx30 channels is shown in Figure $3 A$. As the cell expressing $\mathrm{Cx} 30$ (Cx30-cell) is pulsed to increasingly positive $V_{\mathrm{j}}$, currents decay with increasing rapidity (note that positive junctional currents are shown as downward). In contrast, although instantaneous currents rectify as the Cx30-cell is pulsed to increasingly negative $V_{\mathrm{j}}$ (see below), no significant timedependent current decay is seen on this polarity. The asymmetry in time-dependent current responses is also illustrated in the relationship between macroscopic normalized $G_{j}$ and $V_{\mathrm{j}}$ (the $G_{\mathrm{j}}-V_{\mathrm{j}}$ relationship) (Fig. $3 B$ ) and is likely explained by the difference in $V_{\mathrm{j}}$ gating polarities of $\mathrm{Cx} 32$ and $\mathrm{Cx} 30$ hemichannels. Cx32 has a negative $V_{\mathrm{j}}$ gating polarity (Verselis et al., 1994), meaning that a Cx32 hemichannel closes when the $\mathrm{Cx} 32$-cell is more negative relative to the apposed cell; in contrast, $\mathrm{Cx} 30$ has a positive $V_{\mathrm{j}}$ gating polarity (Dahl et al., 1996). Thus, positive pulses to the Cx30-cell tend to close both the Cx32 and Cx30 hemichannels (Fig. 3B). Cx32/Cx30 currents also exhibit substantial instantaneous rectification (Fig. 3), with $\sim 3.5$-fold greater $I_{\mathrm{j}}$ at $V_{\mathrm{j}}=+100 \mathrm{mV}$ than at $V_{\mathrm{j}}=$ $-100 \mathrm{mV}$. The single-channel conductance of $\mathrm{Cx} 32 / \mathrm{Cx} 30$ channels exhibits fivefold rectification; it is $24 \mathrm{pS}$ when $V_{\mathrm{j}}=$ $-100 \mathrm{mV}$ and $126 \mathrm{pS}$ when $V_{\mathrm{j}}=+100 \mathrm{mV}$ (Fig. $4 \mathrm{~A}$ ). The difference between the extent of rectification of $\mathrm{Cx} 32 / \mathrm{Cx} 30$ channels predicted from the steady-state $G_{\mathrm{j}}-V_{\mathrm{j}}$ plot $(\sim 3.5-$ fold) and the single-channel data (fivefold) may be partially explained by an inability to measure the macroscopic instantaneous current on pulses to large positive voltages because of the rapid closure of these channels or because of the effects of series resistance on the macroscopic recordings (Wilders and Jongsma, 1992).

Compared with $\mathrm{Cx} 32 / \mathrm{Cx} 30$ channels, Cx47/Cx43 channels exhibit more symmetrical properties about $V_{\mathrm{j}}=0$. Macroscopic currents decay increasingly rapidly with increases in the absolute magnitude of $V_{\mathrm{j}}$ (Fig. $3 C$ ). This relative symmetry suggests that both $\mathrm{Cx} 43$ and $\mathrm{Cx} 47$ hemichannels have negative $V_{\mathrm{j}}$ gating polarity, as described previously for $\mathrm{Cx} 43$ hemichannels (Bukauskas et al., 2001). Furthermore, as the absolute value of $V_{\mathrm{j}}$ increases, the steady-state $G_{j}$ declines (Fig. $3 D$ ). There is some asymmetry in both the residual conductances (greater for the Cx43 limb, or negative $V_{j}$ values), and steepness of the $G_{j}-V_{j}$ relationship (greater for $\mathrm{Cx} 47$ limb, or positive $V_{\mathrm{j}}$ values) (Fig. 3D). Rapid gating may have led to underestimation of instantaneous conductance values with large $V_{\mathrm{j}}$ pulses (Fig. $3 D$ ). To correct for this, the dotted line represents the best fit straight line for instantaneous conductance values from -40 to $+40 \mathrm{mV}$. Extrapolating to $\pm 100 \mathrm{mV}, \mathrm{Cx} 47 / \mathrm{Cx} 43$ channels appear to have $\sim 15 \%$ greater conductance when the $\mathrm{Cx} 43$-cell is pulsed to $-100 \mathrm{mV}$ relative to $+100 \mathrm{mV}$. Similarly, the single-channel conductance for Cx47/ Cx43 channels reveals minimal rectification, with greater $I_{\mathrm{j}}$ when the $\mathrm{Cx} 43$-cell is pulsed to $-100 \mathrm{mV}$ relative to $+100 \mathrm{mV}$ (corresponding to $\sim 80$ or $\sim 70 \mathrm{pS}$, respectively) (Fig. $4 B$ ).

To determine whether these two channels show differences in permeability, we assessed dye transfer in isolated Neuro2A cell pairs coupled by $\mathrm{Cx} 32 / \mathrm{Cx} 30$ or $\mathrm{Cx} 47 / \mathrm{Cx} 43$ channels. Previous 
A

\section{$\mathrm{C} \times 32 / \mathrm{C} \times 30$}

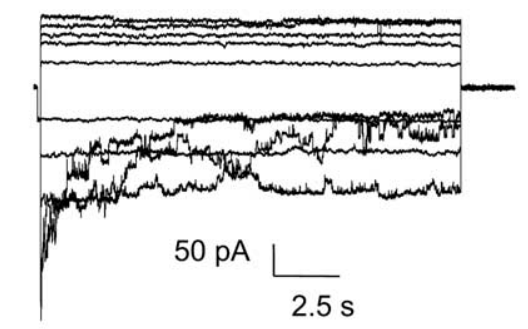

C

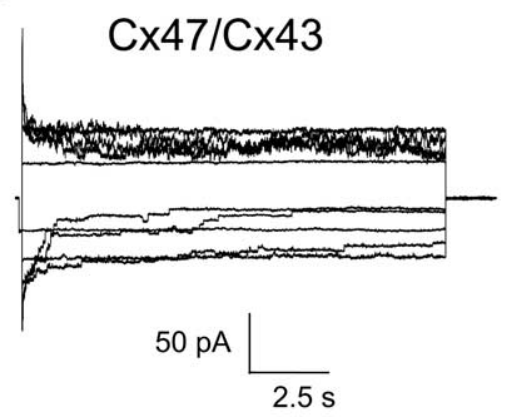

B
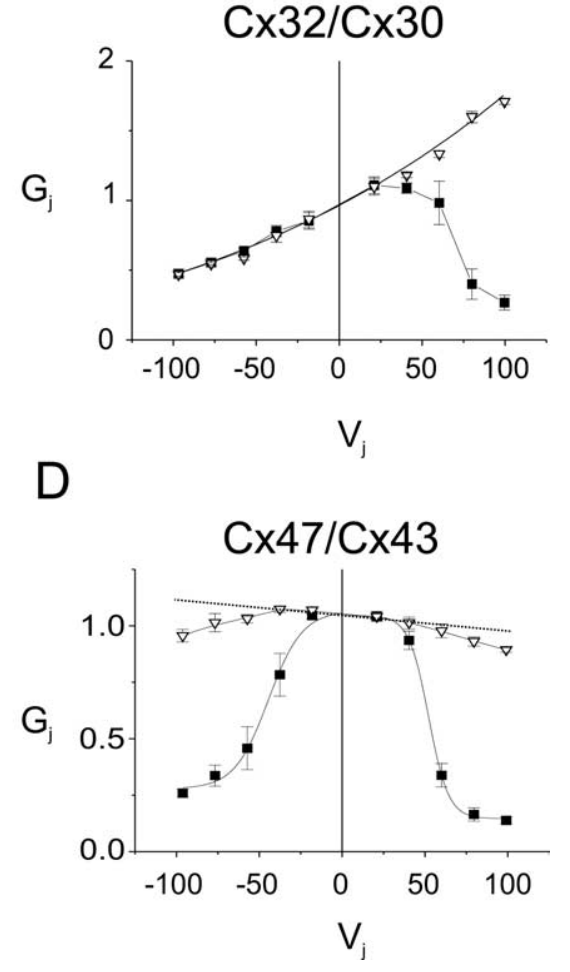

Figure 3. Voltage gating of $\mathrm{C} \times 32 / \mathrm{C} \times 30$ and $\mathrm{C} \times 47 / \mathrm{C} \times 43$ channels. $A, C$, Representative macroscopic current traces for $\mathrm{C} \times 32 / \mathrm{C} \times 30$ $(A)$ and $C \times 47 / C \times 43(C)$ channels. Both cells of a pair were voltage clamped at the same voltage, then cell 1 (expressing $C \times 30$ or $C \times 43$ ) was stepped in $20 \mathrm{mV}$ increments from $V_{\mathrm{j}}=-100$ to $V_{\mathrm{j}}=+100 \mathrm{mV}$, and $/ \mathrm{j}$ s were recorded from cell 2 (expressing $\mathrm{Cx} 32$ or $\mathrm{C} \times 47$ ). Note that the polarity of $I_{j}$ is opposite that of $V_{j}$. For $C \times 32 / C \times 30$ channels, the rate of $/_{j}$ decay increased with increasingly positive $V_{j}$. For the reverse polarity of $V_{j}, l_{j}$ showed slight decay only at $-100 \mathrm{mV}$. The $\mathrm{C} \times 32 / \mathrm{C} \times 30$ channels show substantial instantaneous rectification, with at least 3.5-fold greater current at $V_{j}=+100 \mathrm{mV}$ than at $-100 \mathrm{mV}$. For $C \times 47 / C \times 43$ channels, the rate of current decay increases as the absolute value of $V_{j}$ increases, with some asymmetry in the kinetics of decay. Traces were filtered at $200 \mathrm{~Hz}$. Because all traces were normalized to a $+20 \mathrm{mV}$ prepulse, amplitudes of the unitary transitions shown in these figures may not accurately reflect the single-channel sizes of these channels. However, single-channel conductances calculated from the raw data for this and other similar experiments are in agreement with records such as those shown in Figure 4. B, D, Average normalized $G_{j}-V_{j}$ relations for heterotypic $C \times 32 / C \times 30$ and $C \times 47 / C \times 43$ channels. The average normalized instantaneous (open triangles) and steady-state (filled squares) $G_{j}$ at each $V_{j}$ were calculated from the current traces such as those shown in $\boldsymbol{A}$ and $\boldsymbol{C}$, as described in Materials and Methods. Note that rapid gating to closure may have led to underestimates of instantaneous $G_{\mathrm{j}}$ for $\mathrm{C} \times 32 / \mathrm{C} \times 30$ channels when the $\mathrm{C} \times 30$ cell was stepped to positive voltages $(\boldsymbol{B})$, and on both polarities with $\mathrm{C} 47 / \mathrm{C} \times 43$ channels $(\boldsymbol{D})$.

studies have shown that homotypic channels containing only Cx32 (Elfgang et al., 1995), Cx43 (Elfgang et al., 1995), or Cx47 (Teubner et al., 2001; Orthmann-Murphy et al., 2007) are permeable to LY (MW, 443; valence, -2 ), but homotypic Cx30 channels are either minimally permeable (Beltramello et al., 2003) or impermeable (Manthey et al., 2001). As shown in Figure 5 , when $0.1 \% \mathrm{LY}$ was injected into one cell, we detected LY in the neighboring cell for pairs containing $\mathrm{Cx} 47 / \mathrm{Cx} 43$ (Fig. $5 D$ ), but not $\mathrm{Cx} 32 / \mathrm{Cx} 30$ channels (Fig. 5B). In each case, the recipient cell was isolated from all but the donor cell, and was the only exogenous connexin-expressing cell adjacent to the donor cell. When the concentration of LY was increased to $0.25 \%$, we did detect transfer to the neighboring cell (in four of nine $\mathrm{Cx} 32 / \mathrm{Cx} 30$ pairs) (data not shown), demonstrating that $\mathrm{Cx} 32 / \mathrm{Cx} 30$ channels are less permeable to $\mathrm{LY}$ than are $\mathrm{Cx} 47 / \mathrm{Cx} 43$ channels. In contrast, both $\mathrm{Cx} 32 / \mathrm{Cx} 30$ and $\mathrm{Cx} 47 / \mathrm{Cx} 43$ channels are permeable to 3.3 mm AF350 (MW, 350; valence, -1) (Fig. 5A,C). Similar results were found regardless of which cell of the pair was injected. These electrophysiological and dye transfer results show that Cx32/ $\mathrm{Cx} 30$ and $\mathrm{Cx} 47 / \mathrm{Cx} 43$ channels have different conductance, gating, and permeability properties.
Loss-of-function Cx47 mutants do not efficiently form functional Cx47/Cx43 channels

We showed previously that the $\mathrm{Cx} 47 \mathrm{mu}-$ tants associated with PMLD do not form functional homotypic GJs (OrthmannMurphy et al., 2007). Because O/O junctions are thought not to occur, this finding may be irrelevant for the pathogenesis of PMLD. Thus, we tested the hypothesis that Cx47 mutants cause PMLD by disrupting the formation of $\mathrm{Cx} 47 / \mathrm{Cx} 43$ channels. First, to determine whether Cx47 mutants form overlapping plaques with $\mathrm{Cx} 43$, we mixed HeLa cells stably expressing each Cx47 mutant (P87S, Y269D, or M283T) with cells stably expressing $\mathrm{Cx} 43$ as described above. As shown in Figure 6, both P87S and Y269D were localized to the endoplasmic reticulum (ER), as shown previously (Orthmann-Murphy et al., 2007); as expected, cells expressing these ER-retained mutants did not appear to form overlapping puncta with Cx43. In contrast, cells expressing M283T form overlapping puncta with $\mathrm{Cx} 43$, consistent with our previous findings that this mutant is localized both intracellularly and at the cell membrane (Fig. 6C,D). Nevertheless, all three mutants fail to form functional heterotypic channels with $\mathrm{Cx} 43$ in electrophysiological recordings of cell pairs. The mean $G_{j}$ for pairs containing Cx43 and each of the Cx47 mutants are not significantly different from those of the negative control pairs (P87S/Cx43, $\mathrm{Y} 269 \mathrm{D} / \mathrm{Cx} 43$, or M283T/Cx43 vs Cx43/ CTR or Cx47/CTR, $p>0.05$, Fig. $6 E$ ), but are significantly different from pairs containing WT $\mathrm{Cx} 47 / \mathrm{Cx} 43$ ( $\mathrm{Cx} 47 / \mathrm{Cx} 43$ vs P87S/Cx43, $p<0.001 ; \mathrm{Y} 269 \mathrm{D} / \mathrm{Cx} 43, p<$ $0.05 ; \mathrm{M} 283 \mathrm{~T} / \mathrm{Cx} 43, p<0.01)$. Thus, lossof-function mutations in GJA12 (Cx47) most likely cause PMLD through loss of functional $\mathrm{Cx} 47 / \mathrm{Cx} 43$ channels.

\section{Discussion}

The experiments described here are the first demonstration that two discrete kinds of heterotypic channels (Cx32/Cx30 and $\mathrm{Cx} 47 / \mathrm{Cx} 43)$ are the likely functional channels at $\mathrm{O} / \mathrm{A}$ junctions, and that $\mathrm{Cx} 30 / \mathrm{Cx} 43$ channels probably do not function at $\mathrm{A} / \mathrm{A}$ junctions. Both immunocytochemical and electrophysiological assays support this conclusion. We did not address whether these connexins also form heteromeric hemichannels (and therefore more complicated channels) at O/A and A/A junctions. Our work confirms recordings by dual whole-cell voltage clamping of oocytes showing that $\mathrm{Cx} 32 / \mathrm{Cx} 30$ channels (Dahl et al., 1996), but not Cx43/Cx32 channels (White et al., 1995), are functional. Although previous studies in oocytes had suggested that $\mathrm{Cx} 43 / \mathrm{Cx} 32$ channels were functional (Swenson et al., 1989; Werner et al., 1989), those studies did not suppress the expression of Cx38 (which can form a functional channel with Cx43) (White et al., 1995). Cx32/Cx30 channels exhibit markedly asymmetric instantaneous and steady-state $G_{\mathrm{j}}-V_{\mathrm{j}}$ relationships, whereas those of 
Cx47/Cx43 channels are much more symmetric. The asymmetrical voltagedependent properties displayed by $\mathrm{Cx} 32 /$ Cx30 channels cannot account for the report that dye transfers preferentially in the astrocyte to oligodendrocyte direction (Robinson et al., 1993). Asymmetrical dye transfer between coupled cells violates the second law of thermodynamics (Finkelstein et al., 1994) and is unsubstantiated in compatible heterotypic channels tested to date (Elfgang et al., 1995; Weber et al., 2004).

The connexins studied here have been localized in rodent CNS. By indirect immunofluorescence, $\mathrm{Cx} 43$ and $\mathrm{Cx} 30$ are colocalized in $\mathrm{A} / \mathrm{A}$ and $\mathrm{O} / \mathrm{A}$ junctions and with $\mathrm{Cx} 32$ and $\mathrm{Cx} 47$ at $\mathrm{O} / \mathrm{A}$ junctions (Nagy et al., 2003a; Altevogt and Paul, 2004). Freeze-fracture replica immunogold labeling confirms that $\mathrm{Cx} 30$ and $\mathrm{Cx} 43$ are colocalized in individual astrocyte GJ plaques in A/A and O/A junctions (Rash et al., 2001), and that Cx32 and $\mathrm{Cx} 47$ are colocalized in individual oligodendrocyte GJ plaques in O/A junctions (Li et al., 2004; Kamasawa et al., 2005). The composition of the individual channels that form between two cells cannot be determined by these anatomical techniques, but it has been suggested that $\mathrm{Cx} 32 / \mathrm{Cx} 30$ forms functional channels because Cx30 (but not Cx43) is mislocalized in Gjb1/cx32-null mice (Nagy et al., 2003a; Altevogt and Paul, 2004); because neither study tested whether astrocyte connexins mislocalize in Gja12/cx47-null mice, $\mathrm{Cx} 47 / \mathrm{Cx} 43$ channels were proposed as one of several possible O/A channels.

The model illustrated in Figure 7 incorporates our findings with these anatomical studies. A/A channels are mostly composed of $\mathrm{Cx} 43 / \mathrm{Cx} 43$ channels, fewer $\mathrm{Cx} 30 / \mathrm{Cx} 30$ channels (mostly in gray matter), and no $\mathrm{Cx} 30 / \mathrm{Cx} 43$ channels. O/A channels are composed of $\mathrm{Cx} 47 / \mathrm{Cx} 43$ or $\mathrm{Cx} 32 / \mathrm{Cx} 30$ channels; both may be found in the same GJ plaque. $\mathrm{Cx} 47 / \mathrm{Cx} 43$ channels are mostly localized to oligodendrocyte somata where they outnumber Cx32/Cx30 channels (Nagy et al., 2003a; Altevogt and Paul, 2004; Kleopa et al., 2004; Kamasawa et al., 2005), and to a lesser degree on the outer layer of myelin sheaths (Kamasawa et al., 2005). Cx32/Cx30 channels are mainly found on the outer layer of myelin sheaths, and on oligodendrocyte cell bodies in gray more than in white matter (Kleopa et al., 2004; Kamasawa et al., 2005). Last, Cx29 hemichannels localize to the internode, along the adaxonal membrane of small myelinated fibers in both gray and white matter (Altevogt et al., 2002; Kleopa et al., 2004). Several issues remain unresolved. First, if the prominent expression of Cx32 in white matter (Scherer et al., 1995; Li et al., 1997; Kleopa et al., 2004) results from Cx32/Cx32 homotypic channels between the layers of myelin sheaths (Kamasawa et al., 2005), then these channels are not restricted to paranodes as they appear to be in peripheral myelin (Scherer et al., 1995). Second, if Cx32 on the outer layer of myelin sheaths in white matter has a heterotypic partner, then it is not likely to be $\mathrm{Cx} 30$ or $\mathrm{Cx} 26$, because neither is prominently expressed in white matter (Nagy et al., 1999; Nagy et al., 2001; Altevogt and Paul, 2004) (our unpublished observations).
The roles of these GJ channels of the glial syncytium are currently unknown. GJs transmit action potentials in cardiac muscle and certain neurons, but not in astrocytes or oligodendrocytes, which have only passive membrane currents (Chvatal et al., 1995). One possible role for these GJs, first proposed by Orkand et al. (1966), is that they contribute to the spatial buffering of $\mathrm{K}^{+}$ released during neural activity. They found that astrocytes slowly depolarize after stimulation of amphibian optic nerves as a result of rising extracellular potassium concentration. Because astrocytes are permeable to $\mathrm{K}^{+}$and are coupled to surrounding astrocytes, they could redistribute extracellular $\mathrm{K}^{+}$. The potential mechanisms for $\mathrm{K}^{+}$uptake and disposal have been studied in the brain and retina (Kofuji and Newman, 2004), but it is currently unclear to what extent A/A junctions are required. Wallraff et al. (2006) demonstrated previously that eliminating both Cx30 and $\mathrm{Cx} 43$ in astrocytes modestly diminished $\mathrm{K}^{+}$buffering in the gray matter of hippocampal slices; these authors did not address whether white matter or other gray matter regions were similarly affected. If GJs mediate $\mathrm{K}^{+}$buffering, then $\mathrm{O} / \mathrm{A}$ junctions are probably important, too. In this case, the $\mathrm{K}^{+}$released from myelinated axons likely accumulates in the periaxonal space, where it may be dispersed by entering axons and oligodendrocytes via $\mathrm{Na}$, K-ATPases (Ransom et al., 2000) or possibly by leaking out via paranodal axoglial junctions (MacKenzie et al., 1984). Once $\mathrm{K}^{+}$enters the inner aspect of an oligodendrocyte, it may diffuse via reflexive $\mathrm{Cx} 32 / \mathrm{Cx} 32$ channels (Kamasawa et al., 2005) and then enter astrocytes via O/A channels (Cx32/Cx30 and Cx47/Cx43).

The intercellular movement of $\mathrm{K}^{+}$between glial cells remains to be directly demonstrated, but, regardless of their role, there is substantial genetic evidence that $\mathrm{Cx} 32$ and $\mathrm{Cx} 47$ are essential. Mice that lack both $\mathrm{Cx} 32$ and $\mathrm{Cx} 47$ develop pathological changes in CNS myelin, and early onset of ataxia, seizures and death; these may be caused by the disruption O/A GJs (Menichella et al., 2003; 


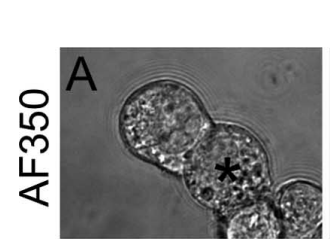

$\mathrm{C} \times 32 / \mathrm{C} \times 30$
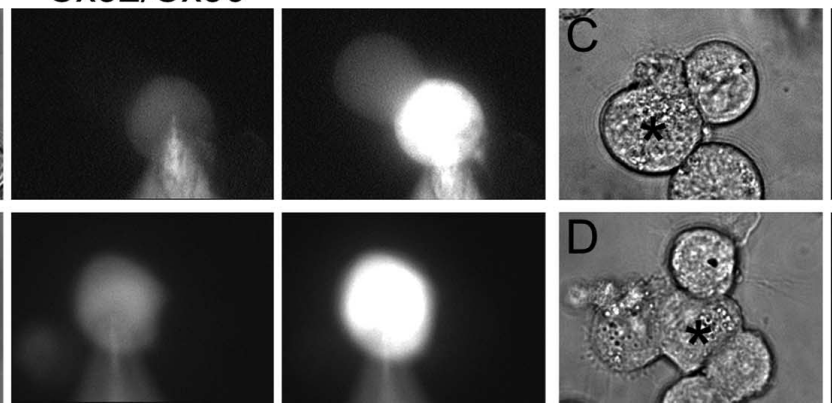

\section{$\mathrm{Cx} 47 / \mathrm{Cx} 43$}

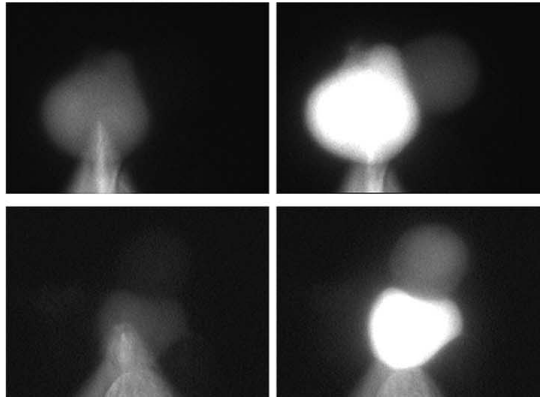

Figure 5. Cx32/Cx30 and Cx47/Cx43 channels have different permeabilities. Neuro2A cells were transiently transfected with plRES2-EGFP or plRES2-DsRed vectors containing Cx30, $C \times 32$, Cx43, or Cx47. After $24 \mathrm{~h}$, EGFP-and DsRed-expressing cells were mixed in a 1 to 1 ratio. $A-D$, One cell of each $C x 32 / C x 30$ or Cx47/Cx43 pair (denoted by an asterisk in each leftmost panel) was patched with an electrode filled with the $\mathrm{GJ}$ permeant dye AF350 $(3.3 \mathrm{~mm} ; \boldsymbol{A}, \boldsymbol{C})$ or $L Y(0.1 \% ; \boldsymbol{B}, \boldsymbol{D})$. For each set of images, the leftmost panels show phase images, the middle panels show epifluorescence images of the patched cell filling with dye, and the right panels show whether dye transferred to a neighboring cell at least $75 \mathrm{~s}$ after establishing whole-cell configuration. Cell pairs containing $C \times 32 / C \times 30$ channels transferred AF350 (A) but not LY $(\boldsymbol{B})$. Cell pairs containing $\left(x 43 / C x 47\right.$ channels are permeable to both AF350 and LY. $G_{\mathrm{j}}$ for each experiment were $19.8 \mathrm{~ns}(\boldsymbol{A}), 12.7 \mathrm{nS}(\boldsymbol{B}), 20.1 \mathrm{nS}(\boldsymbol{C})$, and 6.7 nS (D). AF350: MW, 350; - 1 charge; Lucifer yellow: MW, 443; - 2 charge.

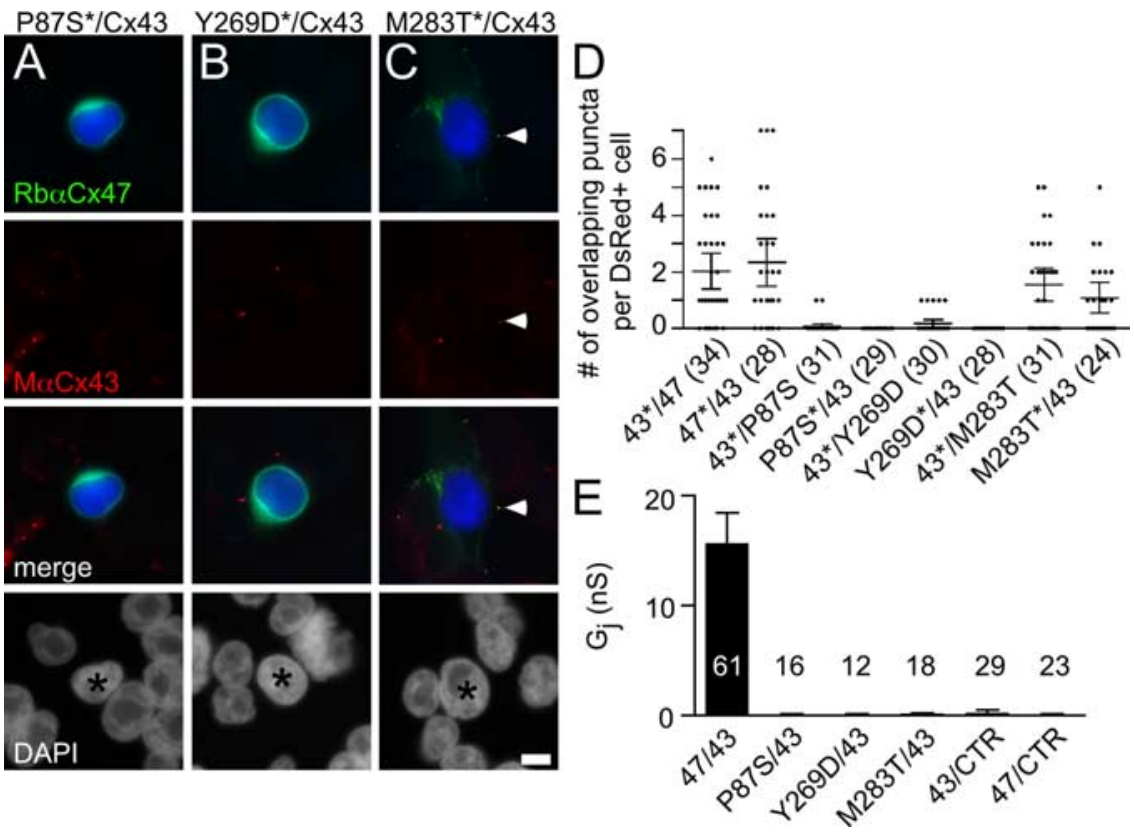

Figure 6. Cx47 mutants do not efficiently form heterotypic channels. A-C, HeLa cells stably expressing Cx47 mutants (P87S, Y269D, or M283T) or (X43 were transiently transfected to express DsRed (DsRed +) and mixed with DsRed - cells in a ratio of 1 to 20 . After $24 \mathrm{~h}$, cells were immunostained as indicated and counterstained for DAPI. One of the two possible pairings for each combination is illustrated. The DsRed + cell is pseudocolored blue in the first and third rows, and indicated by an asterisk in the fourth row. Note that only M283T/CX43 (C) pairings have overlapping puncta at the border of the DsRed signal (arrowhead) similar to $\mathrm{C} \times 47 / \mathrm{C} \times 43$ pairings (Fig. 1), whereas pairing cells expressing $\mathrm{C} \times 43$ with those expressing other mutants do not. $\boldsymbol{D}$, Quantitative summary of three independent experiments such as illustrated in $A-C$. The asterisk denotes the DsRed + cell. Each dot represents the number of overlapping puncta determined for $1 \mathrm{DsRed}+$ cell. In each column, the horizontal bar denotes the mean, the vertical bar represents the $95 \%$ confidence interval, and the total number of DsRed + cells is shown in parentheses. Both pairings of M283T/CX43 (43*/M283T and M283*/43) have overlapping puncta similar to pairings of $\mathrm{C} \times 47 / \mathrm{C} \times 43\left(43^{*} / 47\right.$ and $47^{*} / 43$ ) (data from Fig. 1). $E$, Neuro2A cells were transiently transfected with a pIRES2-EGFP or a pIRES2-DsRed bicistronic expression vector that also contained CX43, Cx47, P87S, Y269D, or M283T. After $24 \mathrm{~h}$, different combinations of red and green cell pairs were generated by mixing the transfected cells at a 1 to 1 ratio, and assessed by dual whole-cell patch clamping $24-48 \mathrm{~h}$ later. For each combination listed on the $x$-axis, the mean and SE of the $G_{\mathrm{j}}$ and number of pairs tested is shown. Using Kruskal-Wallis test followed by Dunn's multiple comparison test, the pairs containing mutant $C \times 47$ have a $G_{j}$ significantly different from that of WT Cx47/Cx43 channels (data from Fig. 2) ( $p<0.001$, P87S/Cx43; $p<0.05, \mathrm{Y} 269 \mathrm{D} / \mathrm{Cx} 43 ; p<0.01$, M283T/Cx43), but not control pairs (43/CTR or 47/CTR)(data from Fig. 2). Scale bar: $10 \mu \mathrm{m}$.

Odermatt et al., 2003). In addition, humans with mutations in GJA12 (Cx47) develop PMLD, a disease with a severe dysmyelinating phenotype (Uhlenberg et al., 2004; Bugiani et al., 2006). We showed previously that expression of these mutations in HeLa cells results in loss-of-function because of both ER- retention and failure to form functional homotypic channels (Orthmann-Murphy et al., 2007); in this study, we found that all three recessive $\mathrm{Cx} 47$ mutants, including the apparent plaque forming M283T mutant, fail to efficiently form functional channels with $\mathrm{Cx} 43$. This, along with the evidence that $\mathrm{O} / \mathrm{O}$ channels do not occur in vivo (Mugnaini, 1986; Rash et al., 2001), suggests that the devastating phenotype of PMLD owes to the loss of $\mathrm{Cx} 47 / \mathrm{Cx} 43$ channels. However, we have not ruled out other potential mechanisms, such as the possibility that these mutants exhibit altered binding partner interactions that affect trafficking or signaling (Giepmans, 2004); alternatively, it is not known whether Cx47 WT or mutants form functional hemichannels (Goodenough and Paul, 2003; Chen et al., 2005). Although Cx47/Cx43 channels appear to be critical for human myelination (Uhlenberg et al., 2004; Bugiani et al., 2006), they may not be required for the formation and/or maintenance of myelin in Gja12/cx47-null mice, which have only mild myelin pathology (Menichella et al., 2003; Odermatt et al., 2003). Perhaps in rodents, $\mathrm{Cx} 32 / \mathrm{Cx} 30$ channels compensate for the loss of $\mathrm{Cx} 47 / \mathrm{Cx} 43$ channels. $\mathrm{Cx} 32 / \mathrm{Cx} 30$ channels do not appear to be critical for CNS myelination, because neither mice nor humans lacking Cx32 have an overt CNS phenotype (Scherer et al., 1998; Hahn et al., 2000). Thus, the role of $\mathrm{Cx} 32 / \mathrm{Cx} 30$ channels in the CNS remains to be elucidated.

Could the distinct functional properties of $\mathrm{Cx} 32 / \mathrm{Cx} 30$ and $\mathrm{Cx} 47 / \mathrm{Cx} 43$ channels that we have shown here have different roles in $\mathrm{O} / \mathrm{A}$ coupling? Given that $\mathrm{Cx} 32 / \mathrm{C} \times 30$ and $\mathrm{Cx} 47 / \mathrm{Cx} 43$ channels are similarly permeable to AF 350 (charge -1 ) but differently permeable to LY (charge -2), other multivalent anions like ATP (Goldberg et al., 2002) or $\mathrm{IP}_{3}$ (Niessen et al., 2000) may also differentially permeate these channels. However, such predictions are difficult to make 


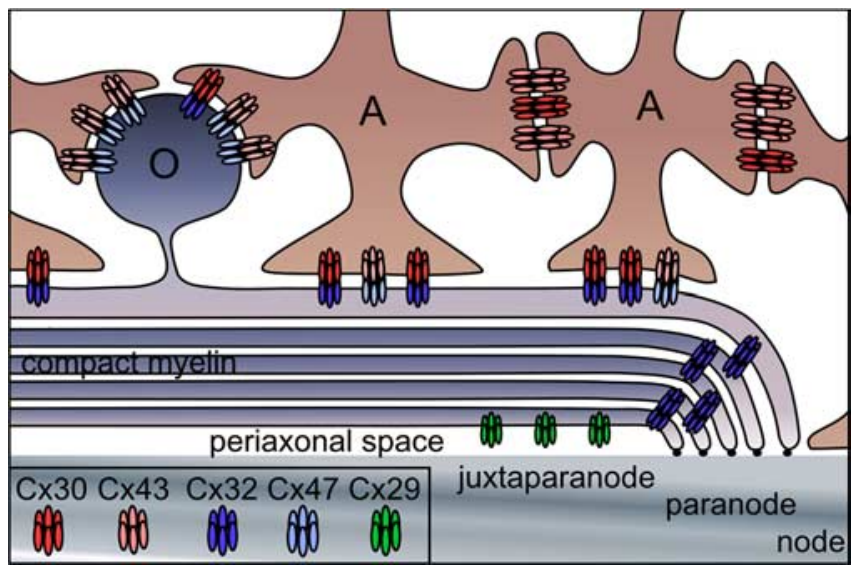

Figure 7. The gap junction network of astrocytes and oligodendrocytes. This drawing depicts our model for the $\mathrm{GJ}$ channels that connect astrocytes $(\mathrm{A})$ to oligodendrocytes $(0)$ and other astrocytes. A/A junctions contain $\mathrm{C} 330 / \mathrm{C} \times 30$ and $\mathrm{C} \times 43 / \mathrm{C} \times 43$ channels; $0 / \mathrm{A}$ junctions contain $\mathrm{C} \times 32 / \mathrm{C} \times 30$ and $\mathrm{C} \times 47 / \mathrm{C} \times 43$ channels. Homotypic $\mathrm{C} \times 32 / \mathrm{C} \times 32$ channels connect layers of myelin sheath at the paranode and incisures (data not shown). (x29 hemichannels are localized to the adaxonal membrane of oligodendrocytes, apposing the axon.

because charge is not the only factor influencing permeability; other factors that likely affect permeability include the size and shape of the permeating species and the molecular architecture of the channel pore (Harris, 2007). Whether the unique permeability and gating properties of $\mathrm{Cx} 32 / \mathrm{Cx} 30$ and $\mathrm{Cx} 47 / \mathrm{Cx} 43$ channels are relevant for O/A coupling remains to be explored.

\section{References}

Abrams CK, Freidin M, Bukauskas F, Dobrenis K, Bargiello TA, Verselis VK, Bennett MV, Chen L, Sahenk Z (2003) Pathogenesis of X-linked Charcot-Marie-Tooth disease: differential effects of two mutations in connexin 32. J Neurosci 23:10548-10558.

Abrams CK, Freidin MM, Verselis VK, Bargiello TA, Kelsell DP, Richard G, Bennett MV, Bukauskas FF (2006) Properties of human connexin 31, which is implicated in hereditary dermatological disease and deafness. Proc Natl Acad Sci USA 103:5213-5218.

Altevogt BM, Paul DL (2004) Four classes of intercellular channels between glial cells in the CNS. J Neurosci 24:4313-4323.

Altevogt BM, Kleopa KA, Postma FR, Scherer SS, Paul DL (2002) Cx29 is uniquely distributed within myelinating glial cells of the central and peripheral nervous systems. J Neurosci 22:6458-6470.

Barrio LC, Suchyna T, Bargiello T, Xu LX, Roginski RS, Bennett MVL, Nicholson BJ (1991) Gap junctions formed by connexins 26 and 32 alone and in combination are differently affected by applied voltage. Proc Natl Acad Sci USA 88:8410-8414.

Beltramello M, Bicego M, Piazza V, Ciubotaru CD, Mammano F, D’Andrea P (2003) Permeability and gating properties of human connexins 26 and 30 expressed in HeLa cells. Biochem Biophys Res Commun 305:1024-1033.

Bruzzone R, White TW, Paul DL (1996) Connections with connexins: the molecular basis of direct intercellular signaling. Eur J Biochem 238:1-27.

Bugiani M, Al Shahwan S, Lamantea E, Bizzi A, Bakhsh E, Moroni I, Balestrini MR, Uziel G, Zebiani M (2006) GJA12 mutations in children with recessive hypomyelinating leukoencephalopathy. Neurology 67:273-279.

Bukauskas FF, Bukauskiene A, Bennett MVL, Verselis VK (2001) Gating properties of gap junction channels assembled from connexin 43 and connexin43 fused with green fluorescent protein. Biophys J 81:137-152.

Chen Y, Deng Y, Bao X, Reuss L, Altenberg GA (2005) Mechanism of the defect in gap-junctional communication by expression of a connexin 26 mutant associated with dominant deafness. FASEB J 19:1516-1518.

Chvatal A, Pastor A, Mauch M, Sykova E, Kettenmann H (1995) Distinct populations of identified glial cells in the developing rat spinal cord splice: ion channel properties and cell morphology. Eur J Neurosci 7:129-142.

Dahl E, Manthey D, Chen Y, Schwarz HJ, Chang YS, Lalley PA, Nicholson BJ, Willecke K (1996) Molecular cloning and functional expression of mouse connexin-30, a gap junction gene highly expressed in adult brain and skin. J Biol Chem 271:17903-17910.
Dermietzel R, Traub O, Hwang TK, Beyer E, Bennett MV, Spray DC, Willecke K (1989) Differential expression of three gap junction proteins in developing and mature brain tissues. Proc Natl Acad Sci USA 86:10148-10152.

Elfgang C, Eckert R, Lichternberg-Frate H, Butterweck A, Traub O, Klein RA, Hulser DF, Willecke K (1995) Specific permeability and selective formation of gap junction channels in connexin-transfected HeLa cells. J Cell Biol 129:805-817.

Filippov MA, Hormuzdi SG, Fuchs EC, Monyer H (2003) A reporter allele for investigating connexin 26 gene expression in the mouse brain. Eur J Neurosci 18:3183-3192.

Finkelstein A, Meister M, Buehler L, Robinson SR, Hampson ECGM (1994) Gap junction and intercellular communications. Science 265:1017-1020.

Furneaux HM, Rosenblum MK, Dalmau J, Wong E, Woodruff P, Graus F, Posner JB (1990) Selective expression of Purkinje-cell antigens in tumor tissue from patients with paraneoplastic cerebellar degeneration. N Engl J Med 322:1844-1851.

Giepmans BN (2004) Gap junctions and connexin-interacting proteins. Cardiovasc Res 62:233-245.

Goldberg GS, Moreno AP, Lampe PD (2002) Gap junctions between cells expressing connexin 43 or 32 show inverse permselectivity to adenosine and ATP. J Biol Chem 277:36725-36730.

Goodenough DA, Paul DL (2003) Beyond the gap: Functions of unpaired connexon channels. Nat Rev Mol Cell Biol 4:285-294.

Hahn AF, Ainsworth PJ, Naus CCG, Mao J, Bolton CF (2000) Clinical and pathological observations in men lacking the gap junction protein connexin 32. Muscle Nerve:S39-S48.

Harris AL (2007) Connexin channel permeability to cytoplasmic molecules. Prog Biophys Mol Biol 94:120-143.

Kamasawa N, Sik A, Morita M, Yasumura T, Davidson KGV, Nagy JI, Rash JE (2005) Connexin-47 and connexin-32 in gap junctions of oligodendrocyte somata, myelin sheaths, paranodal loops and Schmidt-Lanterman incisures: implications for ionic homeostasis and potassium siphoning. Neuroscience 136:65-86.

Kleopa KA, Orthmann JL, Enriquez A, Paul DL, Scherer SS (2004) Unique distributions of the gap junction proteins connexin29, connexin32, and connexin47 in oligodendrocytes. Glia 47:346-357.

Kofuji P, Newman EA (2004) Potassium buffering in the central nervous system. Neuroscience 129:1043-1054.

Li J, Hertzberg EL, Nagy JI (1997) Connexin32 in oligodendrocytes and association with myelinated fibers in mouse and rat brain. J Comp Neurol 379:571-591.

Li X, Ionescu AV, Lynn BD, Lu S, Kamasawa N, Morita M, Davidson KGV, Yasumura T, Rash JE, Nagy JI (2004) Connexin47, connexin29 and connexin32 co-expression in oligodendrocytes and $\mathrm{Cx} 47$ association with zonula occludens-1 (ZO-1) in mouse brain. Neuroscience 126:611-630.

MacKenzie ML, Ghabriel MN, Allt G (1984) Nodes of Ranvier and Schmidt-Lanterman incisures: an in vivo lanthanum tracer study. J Neurocytol 13:1043-1055.

Manthey D, Banach K, Desplantez T, Lee CG, Kozak CA, Traub O, Weingart R, Willecke K (2001) Intracellular domains of mouse connexin26 and-30 affect diffusional and electrical properties of gap junction channels. J Membr Biol 181:137-148.

Menichella DM, Goodenough DA, Sirkowski E, Scherer SS, Paul DL (2003) Connexins are critical for normal myelination in the central nervous system. J Neurosci 23:5963-5973.

Mugnaini E (1986) Cell junctions of astrocytes, ependyma, and related cells in the mammalian central nervous system, with emphasis on the hypothesis of a generalized functional syncytium of supporting cells. In: Astrocytes (Federoff S, Vernadakis A, eds), pp 329-371. Orlando: Academic.

Nagy JI, Patel D, Ochalski PAY, Stelmack GL (1999) Connexin30 in rodent, cat and human brain: selective expression in gray matter astrocytes, colocalization with connexin 43 at gap junctions and late developmental appearance. Neuroscience 88:447-468.

Nagy JI, Li XB, Rempel J, Stelmack G, Patel D, Staines WA, Yasumura T, Rash JE (2001) Connexin26 in adult rodent central nervous system: Demonstration at astrocytic gap junctions and colocalization with connexin 30 and connexin43. J Comp Neurol 441:302-323.

Nagy JI, Ionescu AV, Lynn BD, Rash JE (2003a) Coupling of astrocyte connexins $\mathrm{Cx} 26, \mathrm{Cx} 30, \mathrm{Cx} 43$ to oligodendrocyte $\mathrm{Cx} 29, \mathrm{Cx} 32, \mathrm{Cx} 47$ : implications from normal and connexin 32 knockout mice. Glia 44:205-218.

Nagy JI, Ionescu AV, Lynn BD, Rash JE (2003b) Connexin29 and con- 
nexin32 at oligodendrocyte and astrocyte gap junctions and in myelin of the mouse central nervous system. J Comp Neurol 464:356-370.

Niessen H, Harz H, Bedner P, Kramer K, Willecke K (2000) Selective permeability of different connexin channels to the second messenger inositol 1,4,5-trisphosphate. J Cell Sci 113:1365-1372.

Ochalski PAY, Frankenstein UN, Hertzberg EL, Nagy JI (1997) Connexin- 43 in rat spinal cord: localization in astrocytes and identification of heterotypic astro-oligodendrocytic gap junctions. Neuroscience 76:931-945.

Odermatt B, Wellershaus K, Wallraff A, Seifert G, Degen G, Euwens C, Fuss B, Bussow H, Schilling K, Stenhauser C, Willecke K (2003) Connexin 47 (Cx47)-deficient mice with enhanced green fluorescent protein reporter gene reveal predominant oligodendrocytic expression of $\mathrm{Cx} 47$ and display vacuolized myelin in the CNS. J Neurosci 23:4549-4559.

Orkand PM, Nicholls JG, Kuffler SW (1966) Effect of nerve impulses on the membrane potential of glial cells in the central nervous system of amphibia. J Neurophysiol 29:788-806.

Orthmann-Murphy JL, Enriquez AD, Abrams CK, Scherer SS (2007) Lossof-function GJA12/Connexin47 mutations cause Pelizaeus-Merzbacherlike disease. Mol Cell Neurosci 34:629-641.

Ransom CB, Ransom BR, Sontheimer H (2000) Activity-dependent extracellular $\mathrm{K}^{+}$accumulation in rat optic nerve: the role of glial and axonal $\mathrm{Na}^{+}$pumps. J Physiol (Lond) 522:427-442.

Rash JE, Yasumura T, Dudek FE, Nagy JI (2001) Cell-specific expression of connexins and evidence of restricted gap junctional coupling between glial cells and between neurons. J Neurosci 21:1983-2000.

Robinson SR, Hampson ECGM, Munro MN, Vaney DI (1993) Unidirectional coupling of gap junctions between neuroglia. Science 262:1072-1074.

Scherer SS, Kleopa KA (2005) X-linked Charcot-Marie-Tooth disease. In: Peripheral neuropathy, Ed 4 (Dyck PJ, Thomas PK, eds), pp 1791-1804. Philadelphia: Saunders.

Scherer SS, Deschênes SM, Xu YT, Grinspan JB, Fischbeck KH, Paul DL (1995) Connexin32 is a myelin-related protein in the PNS and CNS. J Neurosci 15:8281-8294.

Scherer SS, Xu YT, Nelles E, Fischbeck K, Willecke K, Bone LJ (1998) Connexin32-null mice develop a demyelinating peripheral neuropathy. Glia 24:8-20.
Swenson KI, Jordan JR, Beyer EC, Paul DL (1989) Formation of gap junctions by expression of connexins in Xenopus oocyte pairs. Cell 57:145-155.

Taylor RA, Simon EM, Marks HG, Scherer SS (2003) The CNS phenotype of $\mathrm{X}$-linked Charcot-Marie-Tooth disease: more than a peripheral problem. Neurology 61:1475-1478.

Teubner B, Odermatt B, Guldenagel M, Sohl G, Degen J, Bukauskas FF, Kronengold J, Verselis VK, Jung YT, Kozak CA, Schilling K, Willecke K (2001) Functional expression of the new gap junction gene connexin47 transcribed in mouse brain and spinal cord neurons. J Neurosci 21:11171125.

Uhlenberg B, Schuelke M, Ruschendorf F, Ruf N, Kaindl AM, Henneke M, Thiele H, StoltenburgDidinger G, Aksu F, Topaloglu H, Nurnberg P, Hubner C, Weschke B, Gartner J (2004) Mutations in the gene encoding gap junction protein alpha 12 (connexin 46.6) cause PelizaeusMerzbacher-like disease. Am J Hum Genet 75:251-260.

Verselis VK, Ginter CS, Bargiello TA (1994) Opposite voltage polarities of two closely related connexins. Nature 368:348-351.

Wallraff A, Kohling R, Heinemann U, Theis M, Willecke K, Steinhauser C (2006) The impact of astrocytic gap junctional coupling on potassium buffering in the hippocampus. J Neurosci 26:5438-5447.

Weber PA, Chang HC, Spaeth KE, Nitsche JM, Nicholson BJ (2004) The permeability of gap junction channels to probes of different size Is dependent on connexin composition and permeant-pore affinities. Biophys J 87:958-973.

Werner R, Levine E, Rabadan-Diehl C, Dahl G (1989) Formation of hybrid cell-cell channels. Proc Natl Acad Sci USA 86:5380-5384.

White TW, Paul DL, Goodenough DA, Bruzzone R (1995) Functional analysis of selective interactions among rodent connexins. Mol Biol Cell 6:459-470.

Wilders R, Jongsma HJ (1992) Limitations of the dual voltage clamp method in assaying conductance and kinetics of gap junction channels. Biophys J 63:942-953.

Willecke K, Eiberger J, Degen J, Eckardt D, Romualdi A, Guldenagel M, Deutsch U, Söhl G (2002) Structural and functional diversity of connexin genes in the mouse and human genome. Biol Chem 383:725-737.

Yeager M, Unger VM, Falk MM (1998) Synthesis, assembly and structure of gap junction intercellular channels. Curr Op Struct Biol 8:517-524. 